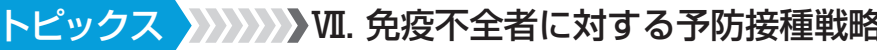

\section{免疫不全者に対する 予防接種戦略}

\section{要 旨}

免疫不全者のワクチンで共通する問題点は, 生ワクチンの接種が難しい 点である. 免疫抑制薬は, 開始してしまえばほぼ生ワクチンは接種できな 小川拓 いため, 開始前に麻疹・風疹・ムンプス・水痘ワクチンを通算 2 回ずつに なるよう追加接種しておくことが必要である. また, 造血細胞移植後に は, 基礎免疫から獲得させる必要があり, 予防接種計画の綿密な立案が必 要となる. また, 脾臓摘出術後等の脾機能低下患者では, 液性免疫不全の 状態が遷延するため, 肺炎球菌やインフルエンザ菌といった細菌による侵 襲性感染症のリスクが高く，予防接種を行うことを忘れてはならない。

[日内会誌 $108 ： 2297 〜 2303 ， 2019]$

Key words 予防接種，ワクチン，固形臟器移植，造血細胞移植，脾機能低下，免疫不全

\section{はじめに}

免疫不全者に対するワクチン接種には, 大き く分けて 3 種類存在する。まず, 固形臟器移植 （solid organ transplantation：SOT）後や関節リ ウマチや膠原病を含む自己免疫疾患, HIV （human immunodeficiency virus）陽性患者等細 胞性免疫不全状態のため予防接種の追加が必要 になる場合である，2つ目に，免疫担当細胞そ のものが入れ替わってしまい, 基礎免疫から免 疫獲得をする必要がある場合で, 造血細胞移植 後患者が相当する. そして, 脾蔵摘出等で生じ る液性免疫不全が挙げられる。これらのカテゴ リ別に予防接種の考え方, 接種方法等を本稿で は概説したい.

\section{1. 固形臓器移植 (SOT) 後患者}

SOT後には, 生涯免疫抑制薬の使用が必要で あり, 国産の麻疹・風疹・ムンプスワクチンは 添付文書上, 免疫抑制薬投与中は接種禁忌であ るため, 移植後は原則的に生ワクチンの接種が できない、そのため, SOTの計画段階で生ワク チン接種を完遂する必要がある.SOT待機患者 は，腎機能低下や肝機能低下等の状況にあり， ワクチンに対する反応がそしいことが予想され るため, 27 日間以上間隔を空けた 2 回の生ワク チン接種が重要である1). 水痘ワクチンだけは 水痘を予防する目的で使用する場合に限り，免 疫抑制薬使用中も禁忌と明示されておらず, 細 胞性免疫の機能が正常に近い場合は接種するこ ともできる，ただし，带状疮疹予防目的で水痘 
ワクチンを免疫抑制薬使用中の患者に接種する ことは添付文書上禁忌とされている.

とは言え, 劇症肝炎後の肝移植等, 移植前に ワクチン接種を行えない症例も存在する。米国 疾病管理予防センター (Centers for Disease Control and Prevention : CDC) のPink Book ${ }^{2)}$ では, プレドニゾロン (prednisolone : PSL) $20 \mathrm{mg} /$ 日 以下（または $2 \mathrm{mg} / \mathrm{kg}$ /日以下）のステロイド投 与であれば，細胞性免疫への影響が少ないとし て，生ワクチン接種を許容している。ただし, PSL以外の免疫抑制薬に関する記載がない点に は注意が必要である.免疫抑制剂使用中のウイ ルス感染症が重篤化しやすいという事実を鑑み ると, 倫理審査委員会の承認と患者本人の同意 を前提に，免疫抑制剤使用中であっても生ワク チン接種の可能性を模索することも必要であろ う.SOT後の生ワクチン接種による有害事象の 報告はあるものの, 致命的な有害事象は現在ま でのところ報告されていない.

不活化ワクチンについては, 移植前後を問わ ず接種することは可能である。ただし，慢性肝 疾患, 慢性腎臓病 (chronic kidney disease : CKD) 患者においては, 健常者よりもワクチンへの免 疫応答は下がるとされる。移植後は免疫抑制薬 の影響によりさらに免疫応答が下がることが予 想されるため, 接種は移植前に行うべきであ る. 予防接種の内容としては, インフルエンザ ワクチン, B型肝炎ワクチンならびに肺炎球菌 ワクチンが特に推奨される. 米国 ${ }^{2)}$, 英国 ${ }^{3)}$ 等の ガイドラインでは，免疫抑制患者における肺炎 球菌ワクチンは 13 価肺炎球菌結合型ワクチン （PCV13）を先行させ，23価肺炎球菌萊膜ポリ サッカライドワクチン（PPV23）を接種する連 続接種が推奨されている. 2 種類のワクチンの 接種間隔は，一般的に 6 力月以上である. 日本 において, PCV13の接種対象が成人では65歳以 上に限定されることは，前述のPCV13，PPV23 連続接種を行ううえで障壁となっている。添付 文書どおりに接種する場合は, 65歳未満の患者
に対しては，PPV23を5 年おきに接種する他に 選択肢がない。次に，ヒトパピローマウイルス （human papillomavirus：HPV）に既感染の腎移 植後患者では，外陰癌のリスクが健常者の 100 倍, 肛門癌のリスクが50倍と報告されており ${ }^{4)}$, HPVワクチン接種が推奨される.9歳以上の女 性が接種対象であるとされている。有害事象の ため定期接種の積極的勧奨が2019年7月現在中 止されているワクチンであるため，接種にあ たっては, 十分な事前説明が必要である. 不活 化帯状疮疹ワクチン (Shingrix ${ }^{\circledR}$ ) が製造承認さ れており, 造血細胞移植後の帯状疱疹を $68 \%$ 減 少させたとする高い効果が報告されている5). 弱毒生ワクチンの使用が禁忌となっている, 帯 状疮疹予防目的での有効性が期待される. な お, 不活化ワクチンを移植後に接種しても, 拒 絶反応の発生に影響を与えないとされている. SOT前に推奨される具体的な予防接種スケ ジュールの 1 例を表 1 に示す.

\section{2. 造血細胞移植後患者}

造血細胞移植後患者においては, 移植前に接 種されたワクチンの効果はないものと考えるべ きである. B細胞が回復するには, 移植後3 3 月 以上の時間を要するため, 不活化ワクチンの接 種開始は移植後 6 力月以降が適切とされる. 推 奨される不活化ワクチンの内容は, 肺炎球菌 (PCV13, PPV23), ジフテリア-百日咳一破傷風, 不活化ポリオ, インフルエンザ菌b型, B型肝 炎，インフルエンザならびに日本脳炎である. SOT後の場合は，移植前の基礎免疫を利用でき たが，造血細胞移植症例においては，基礎免疫 の獲得から開始する必要があるため, 接種回数 が多くなる。生ワクチンは, HIV感染症患者に おける接種基準と同じく, CD4陽性細胞数200/ $\mu 1$ 以上になってから接種することが望ましく, 通常は 1 年以上時間を要する. 現在の日本のガ イドラインでは, 移植後 2 年間の生ワクチン接 
表 135 歳女性の固形臟器移植前ワクチン接種スケジュールの 1 例

\begin{tabular}{|c|c|c|c|c|c|c|c|c|}
\hline ワクチン名 & 接種開始 & 1週後 & 2週後 & 4週後 & 8週後 & 半年後 & 1年後 & \\
\hline B型肝炎 & 0 & & & 0 & & 0 & & \multirow{7}{*}{$\begin{array}{c}\text { 移植 } \\
\text { 2週前には } \\
\text { 完了 }\end{array}$} \\
\hline インフルエンザウイルス & () & & & & & & & \\
\hline HPV & 0 & & & & O & $\bigcirc$ & & \\
\hline 肺炎球菌 & O & & & & & & & \\
\hline 麻疹風疹混合 & & & & $\bullet$ & $\bullet$ & & & \\
\hline ムンプス & & & & 0 & 0 & & & \\
\hline 水痘 & & & & 0 & 0 & & & \\
\hline
\end{tabular}

○ : インフルエンザワクチンは毎年冬に接種することが推奨される.

○: 麻疹・風疹・ムンプス・水痘ワクチンは，それぞれのワクチンが通算2回になるように追加する.

種は推奨されていない。また，T細胞の作用は， 慢性GVHD（graft-versus-host disease）やその治 療目的で使用される免疫抑制薬やステロイドで 減弱する。従って, 慢性GVHDがなく, ステロ イドや免疫抑制薬の使用が終了していることが 生ワクチン接種開始の条件となる ${ }^{6)}$. 造血細胞 移植後に生ワクチンを接種する際は, 基本的に 麻疹・風疹・ムンプス・水痘の全てについて 2 回接種を行うことが多い. 造血細胞移植後に推 奨される予防接種の内容や接種スケジュールに ついて, 表2にまとめた。ただし, 接種スケ ジュールについては, ガイドラインや文献毎に ばらつきがあり，目安と考えるべきである。ま た，上記のワクチンを全て接種すると，かなり の経済的負担を患者に強いることになり，接種 するワクチンの種類を絞らざるを得ない症例も 現実には経験する，現在，造血細胞移植後に定 期予防接種を再度接種するための費用を助成す る自治体は存在するものの, その数は少ない. 今後, ワクチン費用の助成や保険適用等の体制 整備が期待される.

\section{HIV 陽性患者}

HIV 感染症の病態の根幹にあるのは細胞性免 疫不全であるが, 近年, 抗レトロウイルス療法 （antiretroviral therapy：ART）の進歩により, 細
胞性免疫状態が回復し，健常者となんら変わら ない生活をしているHIV陽性患者（people living with HIV：PLWH）も多くなっている. PLWHに おける細胞性免疫は末梢血のCD4 陽性細胞数で 一般的に評価され，200/ $\mu$ 1未満の場合は不活化 ワクチンしか接種できないが，それ以上であれ ば生ワクチンの接種も可能である. PLWHには, 風しん第 5 期定期接種の対象になっている人た ちが多く含まれているため, 接種可能な症例に は風疹含有ワクチンを接種することが重要であ る. 現在, 本邦には, PLWH向けワクチンガイ ドラインは存在しないが, 英国のガイドライ ン7)を引用すると, 生ワクチンとして麻疹・風 疹・ムンプス・水痘ワクチンが, 不活化ワクチ ンとしてインフルエンザ, 破傷風・ジフテリ ア・百日咳, HPV, 肺炎球菌, A型肝炎, B型肝 炎, 髄膜炎菌ワクチンが推奨される. HPVは女 性の子宮頸癌のみならず, 男性の肛門癌や喉頭 癌との関連が明らかになっているため, 本来は 男性も接種が推奨される。ただし，本邦では， 男性に有効な 9 価HPVワクチンは承認されてお らず，今後の課題である. A型肝炎は, PLWHの なかで特に肛門性交を行う同性間性的接触者 (men who have sex with men : MSM) でアウト ブレイクしやすく, B型肝炎は通常の性的接触 でも感染が起きるため, 共に重要である。ただ し, 上記の推奨ワクチンを全て接種すると大変 
表2 造血細胞移植後に推奨される予防接種の内容と接種スケジュール

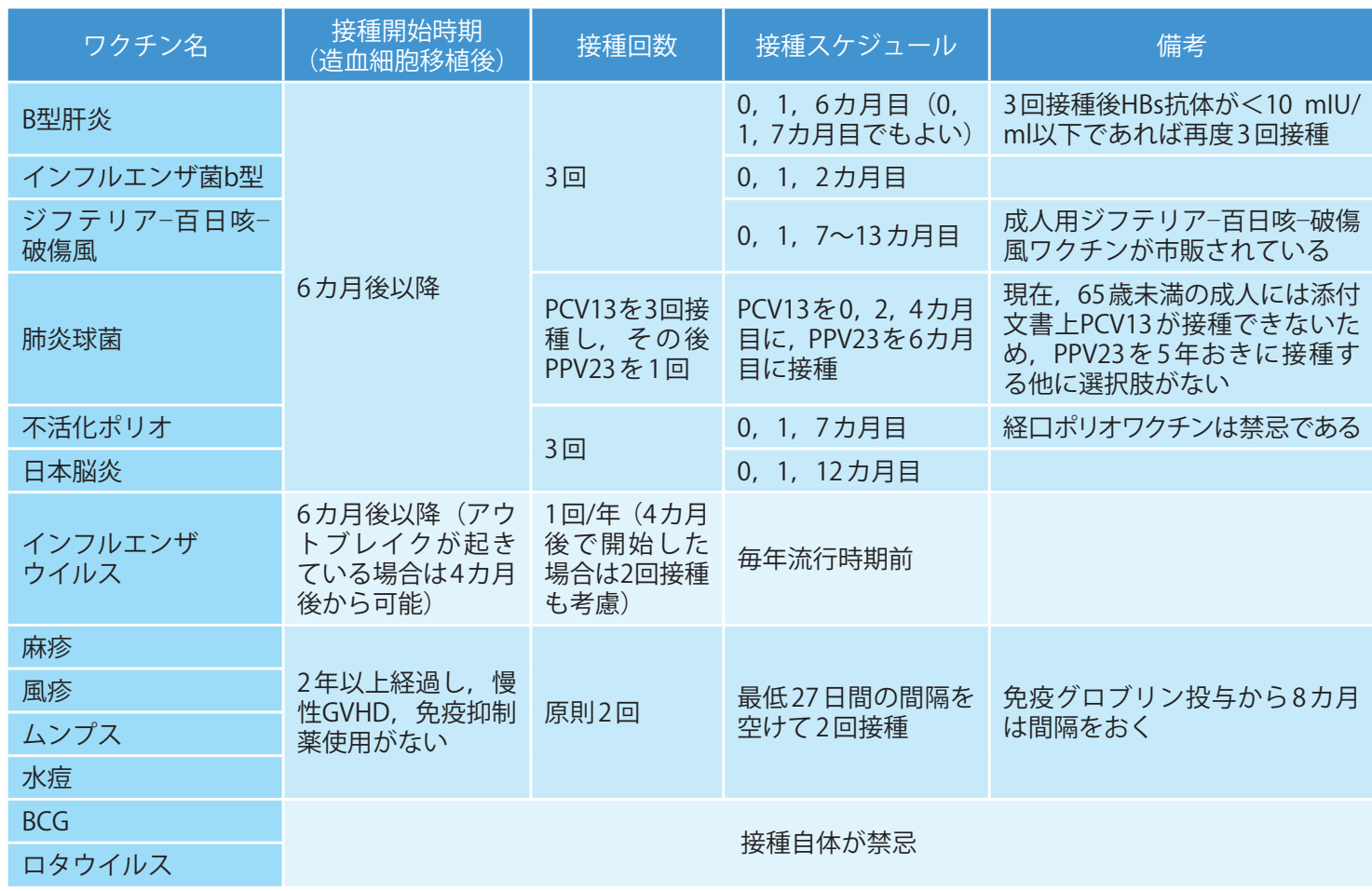

な経済的負担になるため, 患者のライフスタイ ルに合わせ，優先度をつけて接種することが現 実的であると思われる。

\section{4. 自己免疫疾患に対する免疫抑制療法中患者}

自己免疫疾患患者の死亡原因の第 1 位は感染 症であり，予防接種が重要な役割を担う。SOT と同様に，免疫抑制薬が開始されてからの麻 疹・風疹・ムンプスワクチン接種は添付文書で 禁忌とされているため難しい。従って，免疫抑 制薬を開始する前に 2 回接種を完遂させること が重要である.この際, ワクチン由来ウイルス は接種後もしばらくの間体内に残存するため, ワクチン接種は免疫抑制薬開始の 1 力月前には 終了していることが望ましい。また，既に投与 中の免疫抑制薬を一旦中断して生ワクチンを接 種する場合，中断後，接種可能になるまでの期
間ははっきりしていない. しかし, リツキシマ ブが使用されている症例では，3力月以上の間 隔を空ける必要があるとの意見もあり，現実的 ではない. どうしても免疫抑制薬開始後に麻 疹・風疹・ムンプスワクチンを接種する必要が ある場合は, SOT後と同様に, PSL $20 \mathrm{mg}$ /日以

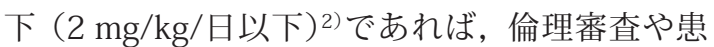
者同意取得等の適正な手続きを経て臨床研究と して接種することも検討される. 不活化ワクチ ンの接種に制限はないが, 免疫抑制薬の種類に よっては, ワクチンに対する免疫応答が低下す ることが明らかになっている．特に推奨される 不活化ワクチンは，インフルエンザワクチン， 肺炎球菌ワクチンならびに帯状疱疹ワクチンで ある ${ }^{9)}$. インフルエンザワクチンは毎年接種が 推奨されるが, メトトレキサート, リツキシマ ブ，トシリズマブならびにアバタセプト使用下 では，免疫応答が低下したと報告されている。 
ただし，免疫抑制薬使用中であっても，抗体価 の上昇は認められており，接種は必要と思われ る. 肺炎球菌ワクチンについては, SOT後同様, PCV13 とPPV23の連続接種が本来は望ましい が, 成人においては, PCV13の接種可能年齢が 65歳以上に限定されているため, それ以下の年 齢の患者に対しては, PPV23の5年おき接種し か選択肢がないのが現状である.肺炎球菌ワク チンの効果は, メトトレキセート, リツキシマ ブ使用中で減弱するとされている，水痘を予防 する目的で免疫抑制療法を受けている患者に水 痘ワクチンを接種することは禁忌になっていな いが，帯状疱疹予防目的の場合，添付文書で禁 忌と記されている. 間もなく帯状疱疹予防を目 的としたリコンビナント帯状疮疹ワクチン $\left(\right.$ Shingrix $\left.{ }^{\circledR}\right)$ が発売される見込みであり, 今後, 免疫抑制薬使用中の患者における帯状疱疹予防 において重要な役割を果たす可能性がある.

\section{5. 担癌患者}

インフルエンザワクチンや肺炎球菌ワクチン が広く接種されている。化学療法中にインフル エンザワクチンを接種しても免疫獲得効果が低 いため, 2 回接種が有効ではないかとの意見も あるが, 現在, 米国CDCの推奨では 1 回接種で 良いとされる. 最近, 多くの固形臟器癌に対し て使用されてきている免疫チェックポイント阻 害薬を使用している症例では，インフルエンザ ワクチンの免疫関連有害事象が出やすくなるこ とが報告されている8)ため, 接種後の有害事象 の出現に注意する必要がある。ただし，この副 反応を理由に，インフルエンザワクチンの接種 を控える必要があるとは考えられていない.

\section{6. 脾機能低下症 (脾臓摘出術後・機能的無脾)}

脾機能低下症の原因として, 脾臓摘出, 脾蔵
低形成ならびに脾梗塞等が挙げられる。一般 に，脾機能低下症においては，萊膜を形成する 菌（肺炎球菌，インフルエンザ桿菌，髄膜炎菌） が侵襲性感染症を起こしやすいとされている. 最近では, 犬の口腔内に常在するCapnocytophaga canimorsusによる劇症感染症も脾機能 低下と関連しているとされている。脾臓摘出後 1 年程度で侵襲性感染症のリスクは最高とな り, 以後生涯高リスクの状態は続く。これらの 細菌による侵襲性感染症は overwhelming postsplenectomy infection（OPSI）と呼ばれ, 死 亡率は $50 \%$ 以上であり, 多くは 24 時間以内に 死亡する. ワクチンの接種時期は, 脾㵴摘出の 14 日以上前が望ましい. 外傷等予期しない脾臓 摘出の場合は, 手術後 14 日以上経過し, 全身状 態が安定してからにすべきである. 最も優先度 が高いのは肺炎球菌ワクチンである.PPV23は 保険適用があると同時に, 含まれている23種類 の血清型による侵襲性肺炎球菌感染症 (invasive pneumococcal disease：IPD）を約 $45 \%$ 減少させ ると報告されている ${ }^{9)}$. 基本的に 5 年おきに接種 することが推奨される. 英国のガイドライン2) では, PCV13をPPV23に先行させて接種するこ とを推奨している．2つのワクチンの接種間隔 は, 脾機能低下の場合に限り, 最低 8 週間まで 短縮できる.PCV13の接種可能年齢に制限があ ることは前述したと抢りであり, 65歳未満の患 者にはPPV23を 5 年おきに接種するしかない. インフルエンザ菌 $\mathrm{b}$ 型ワクチンも接種が行われ ることもあるが, 通常 5 歳までにインフルエン ザ菌b型に対する抗体は既に誘導されているた め, 1 回のみ追加接種する. 髄膜炎菌ワクチン も脾機能低下症例には推奨される。 4 価䯣膜炎 菌結合型ワクチン (MCV4) はA, C, Y, W-135 の 4 つの血清型に対応したワクチンである. MCV4 は2 3 3 月の間隔で 2 回接種し, その後 は 5 年おきに追加接種することが推奨されてい る. CDCは, 血清型Bに対するワクチン接種も行 うべきであるとしている10)が, 現在, 日本では 


\section{表3 脾機能低下症例に対して推奨される予防接種}

\begin{tabular}{|c|c|c|}
\hline ワクチン名 & 接種スケジュール & 備考 \\
\hline 肺炎球菌ワクチン (65歳以上の時) & $\begin{array}{l}\text { PCV13 } \rightarrow P P V 23 を 8 \text { 週間以上の間隔で連 } \\
\text { 続接種 }\end{array}$ & \multirow{2}{*}{$\begin{array}{l}\text { 脾臓摘出 } 14 \text { 日前までに接種を完了 } \\
\text { 緊急の場合は摘出後14日以上経過して } \\
\text { から接種 }\end{array}$} \\
\hline 肺炎球菌ワクチン (65歳未満の時) & PPV23を 5 年おきに接種 & \\
\hline インフルエンザ菌b型ワクチン & 1 回追加 & 5歳以上は抗体を既に有しているため \\
\hline 髄膜炎菌ワクチン & $\begin{array}{l}\text { MCV4を2〜3力月間隔で2回接種し，以 } \\
\text { 後5年おき }\end{array}$ & $\begin{array}{l}\text { MenBも米国では推奨されているが，本 } \\
\text { 邦未承認 }\end{array}$ \\
\hline
\end{tabular}

MenB：髄膜炎菌B型ワクチン

承認されていないため, 未承認ワクチンを扱う 医療機関で接種する必要がある。脾機能低下症 例に対する予防接種については, 表3にまとめ たとおりである。

\section{おわりに}

免疫抑制薬使用中における生ワクチン接種や 65 歳未満の成人に対するPCV13 接種の問題等, 日本に拈いては，未だ免疫不全患者に対するワ クチン接種を行ううえで解決する必要がある問
題が残っている. また, 予防接種の費用は自己 負担となるため, 経済的な事情により必要なワ クチン全てを受けられない患者も一定数存在す る。一部の自治体では助成制度が設けられてい るが，未だ不十分である．今後，日本人に対す る免疫抑制薬投与中の生ワクチン接種の効果や 安全に関する研究, PCV13の適応拡大ならびに 医療費助成制度の拡大等が期待される.

著者のCOI (conflicts of interest) 開示: 本論文発表内容 に関連して特に申告なし 
1) 日本移植学会成人臓器移植予防接種ガイドライン策定委員会編：成人臓器移植予防接種ガイドライン 2018 年版. メディカルレビュー社, 2018.

2) Centers for Disease Control and Prevention (CDC) : Epidemiology and Prevention of Vaccine-Preventable Diseases, The Pink Book : Course Textbook - 13th Edition (2015).

https://www.cdc.gov/vaccines/pubs/pinkbook/downloads/table-of-contents.pdf (accessed on 2019.7.24)

3) Public Health England. Pneumococcal : the green book, chapter 25.

https://assets.publishing.service.gov.uk/government/uploads/system/uploads/attachment_data/file/674074/ GB_Chapter_25_Pneumococcal_V7_0.pdf (accessed on 2019.7.24)

4) Kotton $\mathrm{CN}$ : Immunization after kidney transplantation-what is necessary and what is safe? Nat Rev Nephrol 10 : 555-562, 2014.

5) Bastidas A, et al : Effect of recombinant zoster vaccine on incidence of herpes zoster after autologous stem cell transplantation : a randomized clinical trial. JAMA 322 : 123-133, 2019.

6）日本造血細胞移植学会: 各種予防接種の概要と造血細胞移植患者での実施報告, 予防接種 第3版 造血細胞移植学会 ガイドライン第 1 巻. 2018, 17-33.

7) Geretti AM, et al : British HIV Association Guidelines on the Use of Vaccines in HIV-Positive Adults 2015. HIV Med $17:$ s2-81, 2016.

8) Läubli $\mathrm{H}$, et al : Influenza vaccination of cancer patients during PD-1 blockade induces serological protection but may raise the risk for immune-related adverse events. J Immunother Cancer 6 : 40, 2018.

9）福住宗久, 他：成人侵襲性肺炎球菌感染症由来株の細菌学的解析に関する研究. 成人の侵襲性細菌感染症サーベイ ランスの構築に関する研究 (厚生労働科学研究費補助金 新興・再興感染症及び予防接種政策推進研究事業 研究代表 者：大石和徳）平成 29 年度総括・分担研究報告書. 2018, 63-66.

10) Centers for Disease Control (CDC) : Use of serogroup B meningococcal vaccines in persons aged $\geq 10$ years at increased risk for serogroup B meningococcal disease : Recommendations of the Advisory Committee on Immunization Practices, 2015. MMWR Morb Mortal Wkly Rep 64 : 608-612, 2015. 